\title{
Hubungan Pola Garis Arus Angin (Streamline) dengan Distribusi Hujan di Kalimantan Barat
}

Mega Fitriyawita ${ }^{a, c}$, Muh. Ishak Jumaranga, Apriansyah ${ }^{b}$, Widada Sulistya ${ }^{d}$, Miming Saepudine

aprodi Fisika, FMIPA Universitas Tanjungpura, Pontianak

bProdi Ilmu Kelautan, FMIPA Universitas Tanjungpura, Pontianak

'Stasiun Meteorologi Supadio, BMKG, Pontianak

dPusat Pendidikan dan Pelatihan, BMKG, Jakarta

ePusat Meteorologi Publik, BMKG, Jakarta

*Email : mega_fitriyawita@yahoo.com

\begin{abstract}
Abstrak
Berdasarkan mekanisme pembentukan awan, hujan dibagi menjadi hujan konvektif, hujan orografi, dan hujan konvergensi/frontal. Awan dapat terbentuk apabila uap air mengalami kondensasi di atas permukaan bumi. Salah satu faktor yang sangat berpengaruh untuk peningkatan uap air di atmosfer adalah angin. Peta normal pola garis arus angin (streamline) dan peta normal hujan di Kalimantan Barat periode tahun19812010 digunakan sebagai data untuk mengetahui hubungan pola garis arus angin (streamline)dengan distribusi hujan di Kalimantan Barat menggunakan metode analisis deskriptif. Pengolahan peta streamline menggunakan software GrADS, sedangkan peta normal curah hujan diperoleh dari pengukuranyang dilakukan oleh Stasiun Klimatologi Mempawah. Secara umum puncak hujan di Kalimantan Barat terjadi pada Maret-April dan November-Desember, sedangkan lembah hujan terjadi pada Februari dan JuliAgustus. Secara spesifik daerah hulu Kalimantan Barat memiliki curah hujan lebih tinggi daripada daerah hilir Kalimantan Barat. Pada Maret-April yang merupakan puncak hujan pertama di Kalimantan Barat, terbentuk daerah konvergensi dan pusaran siklonik di sekitar daerah hulu Kalimantan Barat (Kabupaten Kapuas Hulu dan sekitarnya). Pada puncak hujan kedua yaitu November-Desember, terdapat daerah konvergensidan daerah belokan angin di Kalimantan Barat.
\end{abstract}

Kata Kunci : Streamline, hujan

\section{Latar Belakang}

Salah satu faktor yang sangat berpengaruh untuk peningkatan uap air di atmosfer adalah kecepatan angin [1]. Sampai batas tertentu, kenaikan kecepatan angin memindahkan air yang menguap dan karenanya persediaan air (kebasahan) dalam udara di atas air nilainya rendah. Berdasarkan letak geografis yang spesifik, Kalimantan Barat tepat dilalui oleh garis Khatulistiwa (garis lintang $0^{\circ}$ ) tepatnya di atas Kota Pontianak. Karena pengaruh letak ini pula, maka Kalimantan Barat adalah salah satu daerah tropik dengan suhu udara cukup tinggi serta diiringi kelembaban dan curah hujan yang tinggi. Secara umum, daratan Kalimantan Barat merupakan dataran rendah dan mempunyai ratusan sungai yang aman bila dilayari, sedikit berbukit yang menghampar dari barat ke timur sepanjang Lembah Kapuas serta Laut Natuna/Selat Karimata. Wilayah daratan ini diapit oleh dua jajaran pegunungan yaitu, Pegunungan Kalingkang/Kapuas Hulu di bagian utara dan Pegunungan Schwanerdi selatan sepanjang perbatasan dengan Provinsi Kalimantan Tengah. Daerah Kalimantan Barat termasuk salah satu daerah yang dapat dijuluki Provinsi Seribu Sungai. Sungai besar utama adalah S. Kapuas, yang juga merupakan sungai terpanjang di Indonesia (1.086 km), yang mana sepanjang $942 \mathrm{~km}$ dapat dilayari. Sungai-sungai besar lainnya adalah: S. Melawi, (dapat dilayari $471 \mathrm{~km})$, S. Pawan (197 km), S. Kendawangan (128 km), S. Jelai (135 km), S. Sekadau (117 km), S. Sambas (233 km), S. Landak (178 km). Jika sungai-sungai sangat menonjol jumlahnya di Kalimantan Barat, maka sebaliknya yang terjadi dengan danau. Dari danau-danau yang ada hanya dua yang cukup berarti. Kedua danau ini adalah Danau Sentarum (seluas 117.500 hektar) dan Danau Luar I (seluas 5.400 hektar) yang berada di Kabupaten Kapuas Hulu [2].

Yudha melakukan kajian keterkaitan angin di lapisan bawah troposfer tepatnya pada lapisan $850 \mathrm{mb}$ yaitu angin zonal dan meridional terhadap curah hujan di atas wilayah kota Makassar periode tahun 1983 sampai 2012 secara tahunan maupun saat kondisi El-Nino atau La-Nina. Hasil penelitiannya menunjukkan angin zonal lebih dominan dan memiliki korelasi terhadap anomali curah hujan lebih besar dibandingkan dengan angin meridional [3]. Nuraya dkk melakukan penelitian analisis hujan ekstrim berdasarkan parameter angin dan uap air di Kototabang Sumatera Barat menggunakan data angin zonal dan meridional dari EAR (Equatorial Atmosphere Radar), data radiometer 
uap air, data IUA (Integrasi Uap Air) serta data curah hujan dari Maret 2002 s.d. Agustus 2004 [4]. Hasilnya menunjukkan bahwa kecepatan angin, arah angin dan uap air maksimum terjadi pada tanggal 29 Maret 2004 dengan kecepatan angin sebesar $4 \mathrm{~m} / \mathrm{s}$ dominan ke arah barat dan uap air sebesar 8 gram $/ \mathrm{m}^{3}$, serta PWV (Precitable Water Vapor) tertinggi terjadi pada bulan Maret. Dalam rentang waktu penelitian hujan ekstrim terjadi sebanyak 3 kejadian. Kecepatan angin dan uap air lebih besar terjadi saat hujan ekstrim serta arah angin saat hujan ekstrim dominan ke arah barat. Rahmani dkk meneliti tentang perhitungan potensi energi angin berdasaerkan data kecepatan angin tahun 2006 s.d. 2015 di 14 kabupaten/kota di Kalimantan Barat menggunakan software surfer dan dianalisis berdasarkan empat kondisi musim di Indonesia[5]. Hasil perhitungan menunjukan arah angin dominan yang terjadi di daerah Kalimantan Barat pada Musim Barat (DesemberJanuari-Februari) dari arah barat laut bergerak menuju timur dan timur laut, arah angin bervariasi ditunjukkan pada kondisi peralihan I (Maret-April-Mei) di wilayah Kalimantan Barat dimana arah angin ada yang bertiup dari arah utara dan tenggara maupun barat, arah angin dominan pada Musim Timur (Juni-Juli-Agustus) di wilayah Kalimantan Barat bertiup dari arah timur, serta arah angin dominan kondisi peralihan II (September-Oktober-Nopember) di perairan pesisir Kalimantan Barat bertiup dari arah tenggara.

Telah adanya penelitian sebelumnya yang mengkaji tentang keterkaitan komponen angin zonal dan meridional di troposfer lapisan $850 \mathrm{mb}$ (millibar) terhadap curah hujan di Makassar serta keterkaitan antara kecepatan angin (menggunakan data angin zonal dan meridional) dan uap air saat cuaca ekstrim di Kototabang, serta ingin memperdalam penelitian yang telah ada mengenai kondisi angin pada empat musim di Kalimantan Barat, maka penulis ingin melakukan penelitian serupa namun pada lapisan yang lebih rendah lagi yaitu pada ketinggian $925 \mathrm{mb}$ (millibar)atau 3000 feet di wilayah Kalimantan Barat menggunakan streamline/garis arus angin yang merupakan penggabungan dari komponen angin zonal dan meridional tersebut.Penelitian ini mengkajibagaimana hubungan pola yang terdapat garis arus angin (streamline)dengan distribusi curah hujan di wilayah Kalimantan Barat. Tujuan dari penelitian ini yaitu untuk mengetahui pola-pola yang biasa terbentuk pada streamline sepanjang tahun pada umumnya, dan saat puncak hujan pada khususnya.

Analisis streamline dilakukan mulai ketinggian 3000 kaki hingga puncak atmosfer (lapisan $925 \mathrm{mb}$ ke atas) untuk melihat angin yang sebenarnya tanpa adanya pengaruh gaya gesekan dan pengaruh dengan topografi [6]. Gerakan udara tidak lurus tetapi mengikuti suatu lintasan yang melengkung maka resultan dari gaya gradien tekanan dan gaya corioli harus menghasilkan gaya sentripetal yangdapat mengimbangi gayasentripugal untuk dapat bergerak melengkung, gerak angin tersebut dinamakan angin gradient.Tanda positif menyatakan gerak siklonal di Belahan Bumi Utara dan tanda negatif menyatakan gerak antisiklon di Belahan Bumi Utara [7].

$$
V_{\text {grad }}=-\frac{1}{2} f r \pm \sqrt{\frac{f^{2} r^{2}}{4}+\frac{r}{\rho} \frac{\partial p}{\partial r}}
$$

dengan: $V_{\text {grad }}=$ angin gradien

$$
\begin{array}{ll}
f & =\text { faktor coriolis } \\
r & =\text { jari-jari kelengkungan isobar } \\
\rho & =\text { rapat massa udara } \\
\frac{\partial p}{\partial r} & =\text { gradien tekanan pada isobar } \\
& \text { melengkung }
\end{array}
$$

Hujan atau endapan didefinisikan sebagai air yang yang jatuh ke permukaan bumi. Air yang jatuh ke permukaan bumi tersebut dapat berbentuk padat seperti batu es dan salju maupun berbentuk cair seperti air hujan. Curah hujan diukur dalam satuan millimeter (mm). Jumlah curah hujan $1 \mathrm{~mm}$ berarti air hujan yang menutupi permukaan tanah setinggi $1 \mathrm{~mm}$ dalam luasan $1 \mathrm{~m}^{2}$ dengan kata lain volumenya $1 \mathrm{~L}$ $\left(\mathrm{dm}^{3}\right)$, dimana tidak ada air yang menguap ataupun meresap ke dalam tanah [8]. Ada tiga jenis hujan yaitu hujan konvektif yang disebabkan oleh gaya apung thermal akibat pemanasan matahari, hujan orografi yang disebabkan oleh efek pegunungan, dan hujan konvergensi atau frontal yang disebabkan oleh pertemuan udara yang sama sifat fisisnya (hujan konvergensi) atau mempunyai sifat fisis berbeda (hujan frontal). Sumber curah hujan di wilayah Indonesia adalah pertumbuhan dengan konveksi dari awan konvektif atau gabungan dengan faktor lain seperti konvergensi, orografik, atau arus siklonik [9].

Berikut ini beberapa kriteria curah hujan yang dikeluarkan oleh Badan Meteorologi Klimatologi dan Geofisika [10]:

a) Hujan Sangat Ringan: Intensitas $<1 \mathrm{~mm}$ dalam 1 jam; atau < 5mm dalam 24 jam

b) Hujan Ringan: Intensitas 1-5 mm dalam 1 jam; atau 5-20 mm dalam 24 jam

c) Hujan Sedang: Intensitas 5-10 mm dalam 1 jam; atau 20-50 mm dalam 24 jam 
d) Hujan Lebat: Intensitas 10-20 mm dalam 1 jam; atau 50-100 mm dalam 24 jam

e) Hujan Sangat Lebat: Intensitas $>20 \mathrm{~mm}$ dalam 1 jam; atau > $100 \mathrm{~mm}$ dalam 24 jam

\section{Metodologi}

Daerah penelitian ini mencakup Provinsi Kalimantan Barat yaitu di antara garis $2^{\circ} 08 \mathrm{LU}$ serta $3^{\circ} 05$ LS serta di antara $108^{\circ} 0$ BT dan $114^{\circ} 10$ BT pada peta bumi [11].

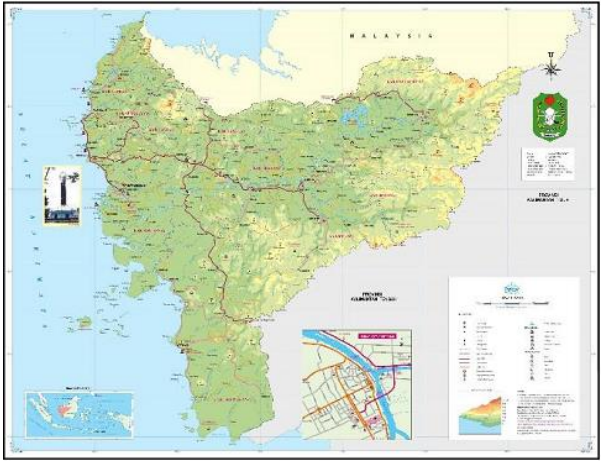

Gambar 1. Peta daerah penelitian[12]

Data yang digunakan dalam penelitian ini mencakup:

a) Peta normal curah hujan rata-rata bulanan (tahun1981-2010) wilayah Kalimantan Barat yang didapat dari Stasiun Klimatologi Siantan,

b) Data reanalisis angin zonal bulanJanuariDesember selama periode 1981-2010 yang diakses dari https://psl.noaa.gov/cgibin/data/composites/printpage.pl,

c) Data reanalisis angin meridional bulan Januari-Desember selama periode 19812010 yang diakses dari https://psl.noaa.gov/cgibin/data/composites/printpage.pl.

Proses pengerjaan penelitian ini melalui 3(tiga) tahapan. Tahapan pertama yaitu melakukan identifikasi terhadap normal curah hujan. Pada tahapan kedua dilakukan proses pengolahan data reanalisis dengan menggunakan GrADS untuk mendapatkan data normal streamlineIndonesia. Selanjutnya, pada tahap ketiga dilakukan analisis deskriptif terhadap hasil pengolahan data renalisis.

Secara garis besar, penelitian ini merupakan penelitian kualitatif yang bersifat deskriptif analitik karena menekankan pada analisis dari suatu kejadian yang terjadi di lapangan sebagai bahan kajian lebih lanjut untuk menjawab mengapa dan bagaimana suatu fenomena terjadi. Pendekatan dalam penelitian ini menggunakan pendekatan induktif karenadidasari pada fakta empiris. Analisis desktiptif dalam penelitian ini yaitu melihat polapola yang muncul pada streamline, melingkupi:

a. Lokasi dari pola-pola yang khas pada streamline angin seperti daerah belokan angin (shearline), daerah berkumpulnya angin (konvergensi), daerah terberainya angin (divergensi), daerah pusaran angin masuk (siklonik), daerah pusaran angin keluar (antisiklonik), daerah angin teduh (netral point), dan sebagainya, dan menghubungkannya dengan distribusi hujan di Kalimantan Barat,

b. Asal massa udara yang masuk ke wilayah Kalimantan Barat saat puncak hujan dan melihat hubungannya dengan distribusi hujan di Kalimantan Barat.

Diagram alir penelitian ditunjukkan pada gambar 2.

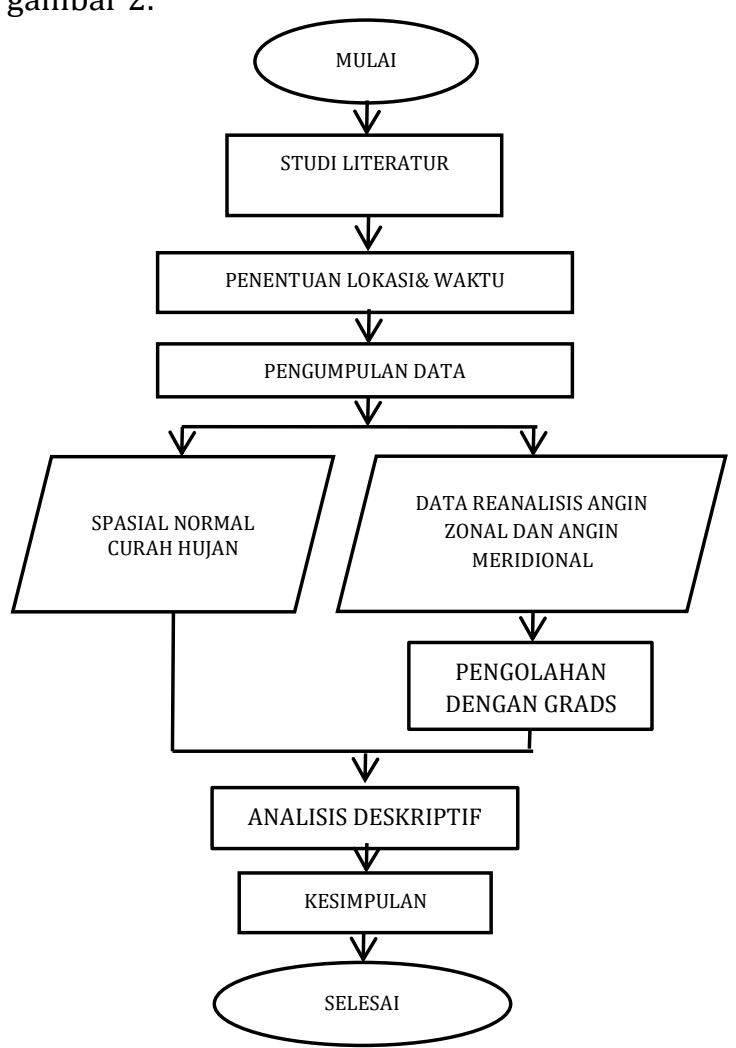

Gambar 2. Diagram alir penelitian

GrADS (Grids Analysis and Display System) adalah sebuah program tools interaktif yang digunakan untuk memudahkan akses, manipulasi, dan visualisasi data ilmu bumi. GrADS mendukung banyak format file data, termasuk biner (stream atau sequential), grib (versi 1 dan 2), NetCDF, HDF-SDS. GraDS menggunakan 4-Dimensional data: bujur, lintang, tingkat vertikal, dan waktu [13]. Pada penelitian ini GrADS digunakan untuk memvisualisasikan data model reanalisis dengan menggunakan script tertentu. 


\section{Hasil dan Pembahasan}

Angin adalah udara yang bergerak dari tekanan tinggi menuju tekanan rendah. Arah angin adalah penjuru darimana angin berhembus atau datang dan dinyatakan dalam derajat yang ditentukan dengan arah perputaran jarum jam dan dimulai dari titik utara bumi. Kecepatan angin adalah kecepatan dari menjalarnya garis arus dan dinyatakan dalam knot atau kilometer perjam maupun dalam meter perdetik [14]. Angin dipengaruhi oleh gaya gradient tekanan, gaya Coriolis, dan gaya gesek.

Streamline angin merupakan kondisi arus angin yang bertiup yang digambar berdasarkan garis singgung atau sejajar dengan data angin pada kawasan mereka berada [15]. Analisis streamline dilakukan mulai ketinggian 3000 kaki hingga puncak atmosfer (lapisan $925 \mathrm{mb}$ ke atas) untuk melihat angin yang sebenarnya tanpa adanya pengaruh gaya gesekan dan pengaruh dengan topografi.

Beberapa pola yang mungkin muncul dalam suatu streamline meliputi:

a) Kovergensi yaitu daerah pertemuan angin dimana pada daerah ini kecepatan anginnya paling rendah dari kondisi sekitar. Konvergensi pada lapisan bawah berkaitan dengan daerah naiknya masa udara yang berpotensi memicu terbentuknya awanawan kovektif penyebab cuaca buruk.

b) Divergensi yaitu daerah terberainya angin dimana pada daerah ini kecepatan anginnya paling kencang dari kondisi sekitarnya.
Divergensi pada lapisan bawah berkaitan dengan terberainya masa udara sehingga kondisi cuaca pada daerah tersebut umumnya cerah.

c) Daerah netral/netral point yaitu daerah perpotongan antara konvergensi dan divergensi. Di dalam netral poin kecepatan anginnya lemah dan mendekati nol.

d) Shearline/belokan angin yaitu daerah dimana suatu angin berbelok paling tidak $90^{\circ}$. Shearline berkaitan dengan daerah berkumpulnya massa udara sehingga memicu pertumbuhan awan-awan penyebab cuaca buruk.

e) Pusaran masuk (siklonik) yaitu daerah dimana terjadi sirkulasi angin tertutup yang arahnya masuk. Kondisi cuaca di daerah siklonik pada lapisan bawah yaitu terbentuknya banyak awan penyebab cuaca buruk dan badai. Arah pusaran siklonik yaitu searah jarum jam untuk Belahan Bumi Selatan (BBS) dan berlawan arah jarum jam untuk Belahan Bumi Utara (BBU).

f) Pusaran keluar (antisiklonik) yaitu daerah dimana terjadi sirkulasi angin tertutup yang arahnya keluar. Kondisi cuaca di daerah antisiklonik pada lapisan bawah yaitu cuaca yang cenderung cerah dan kelembaban udara cenderung kering. Arah pusaran antisiklonik yaitu berlawanan arah jarum jam untuk Belahan Bumi Selatan (BBS) dan searah jarum jam untuk Belahan Bumi Utara (BBU).

\subsection{Normal curah hujan bulanan di Kalimantan Barat}

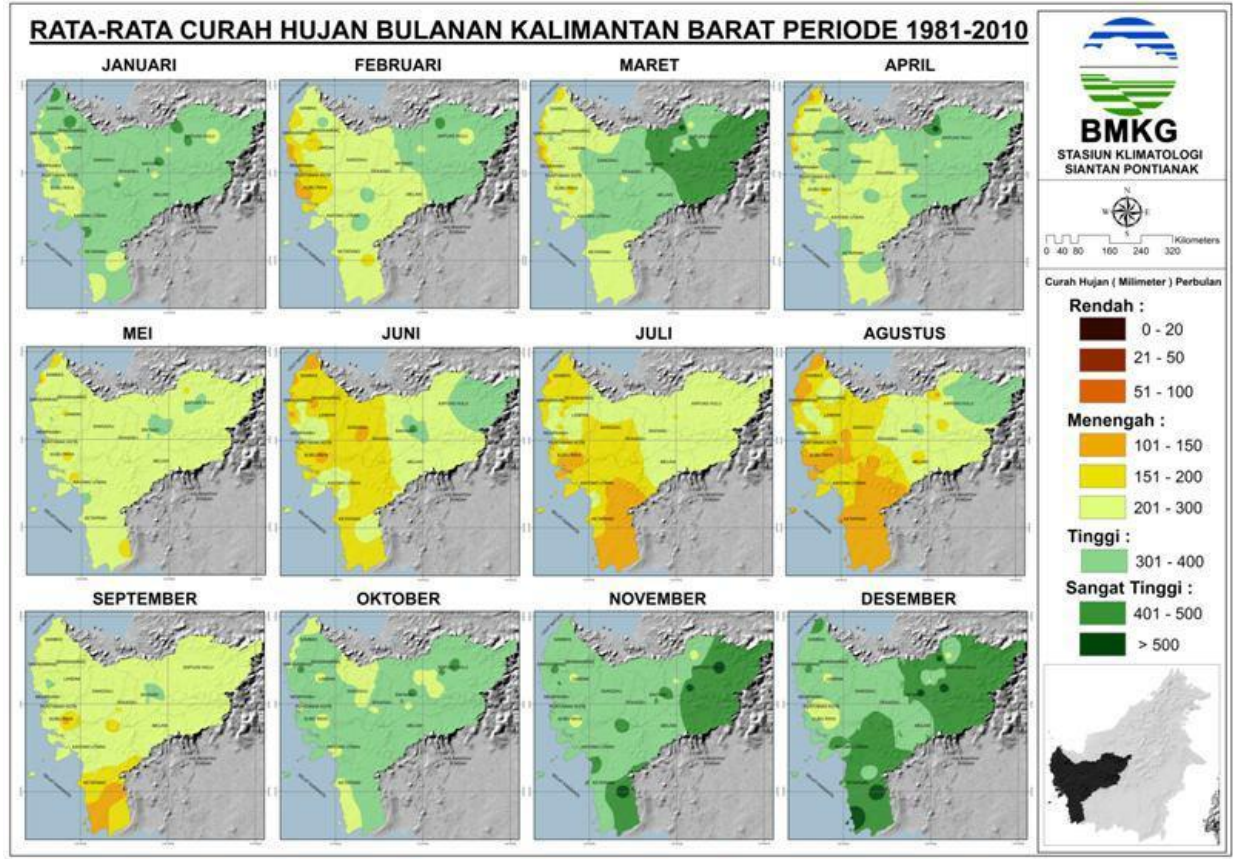

Gambar 3. Peta normal curah hujan bulanan Kalimantan Barat Periode 1981-2010 
Dari Gambar 3 diketahui bahwa secara umum curah hujan rata-rata di Kalimantan Barat berkisar antara $101 \mathrm{~s} / \mathrm{d}>500$ $\mathrm{mm} /$ bulan (kategori menengah-sangat tinggi). Intensitas curah hujan tertinggi terjadi pada bulan Maret-April dan November-Desember dimana curah hujan rata-rata berkisar 301-500 mm/bulan. Pada bulan Maret-April, intensitas curah hujan tertinggi terjadi di sebagian wilayah Kabupaten Sintang dan Kapuas Hulu dengan curah hujan rata-rata 400-500 mm/bulan bahkan dapat mencapai >500 $\mathrm{mm} /$ bulan.Pada bulan NovemberDesember, intensitas curah hujan tertinggi terjadi di sebagian wilayah Kabupaten Ketapang, Sintang, dan Kapuas Huludengan curah hujan rata-rata 400-500 mm/bulan, di sebagian wilayah bahkan mencapai $>500$ $\mathrm{mm} /$ bulan. Sedangkan intensitas curah hujan terendah terjadi pada sekitar bulan Februari dan Juli-Agustus yaitu hanya berkisar 101-150 mm/bulan. Pada bulan Februari, intensitas curah hujan terendah terjadi di sebagian wilayah Kabupaten Kubu Raya, Mempawah, dan Kota Pontianak dengan curah hujan terendah berkisar 101$150 \mathrm{~mm} /$ bulan.Pada bulan Juli-Agustus, intensitas curah hujan terendah terjadi di sebagian wilayah Kabupaten Ketapang, Kubu Raya, dan Sambas dengan curah hujan terendah berkisar 101-150 mm/bulan.

\subsection{Normal curah hujan dan streamline} bulan Januari

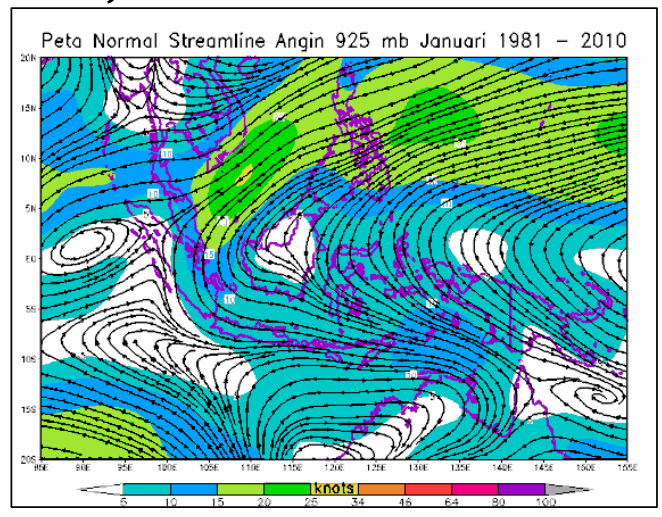

Gambar 4. Peta normal streamline Indonesia bulan Januari periode 1981-2010

Berdasarkan Gambar 3, diketahui bahwa pada bulan Januari secara umum intensitas curah hujan yang terjadi di Kalimantan Barat berkisar 301-400 $\mathrm{mm} /$ bulan dengan kategori tinggi. Namun untuk sebagian wilayah Kabupaten/Kota: Kubu Raya, Mempawah, dan Pontianak curah hujan yang terjadi berkisar 201-300 $\mathrm{mm} /$ bulan dengan kategori menengah.
Bila dikaitkan dengan angin, maka berdasarkan peta normal streamlinebulan Januari untuk periode yang sama yakni 1981-2010, maka angin yang bertiup untuk wilayah Indonesia secara umum yaitu dari barat, dan secara khusus di wilayah Kalimantan Barat angin yang berhembus adalah dari Samudera Pasifik yang kemudian memasuki Laut China Selatan, Selat Karimata dan kemudian berbelok menuju Australia sehingga terdapat daerah belokan angin (shearline) di sekitar Kalimantan Barat dengan kecepatan angin berkisar 5-10 knots (lihat Gambar 4). Angin yang berhembus dari Samudera Pasifik tersebut membawa banyak uap air yang cukup untuk proses pembentukan awan hujan. Selain itu, adanya shearline mengakibatkan massa udara berkumpul di sekitar lokasi shearline sehingga memicu aktivitas konvektif pembentukan awanawan hujan.

\subsection{Normal curah hujan dan streamline bulan Februari}

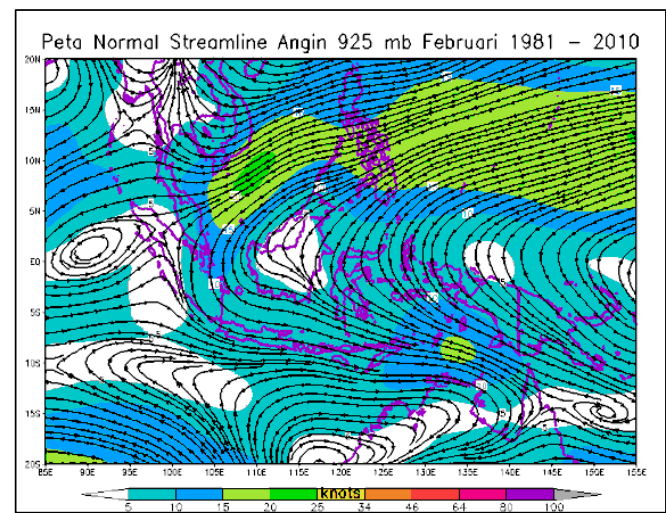

Gambar 5. Peta normal streamline

Indonesia bulan Februari periode 19812010

Berdasarkan Gambar 3, diketahui bahwa pada bulan Februari secara umum intensitas curah hujan yang terjadi di Kalimantan Barat berkisar 201-300 $\mathrm{mm} /$ bulan dengan kategori menengah. Namun untuk sebagian wilayah Kabuapten/Kota: Kubu Raya, Mempawah, Bengkayang, Sambas, Singkawang, dan Pontianak curah hujan yang terjadi lebih rendah dari $200 \mathrm{~mm} /$ bulan bahkan di sebagian wilayah Kabupaten Kubu Raya dan Mempawah hanya 101-150 mm/bulan. Selain itu, terdapat pula curah hujan dengan intensitas 301-500 mm/bulan yaitu di sebagian wilayah Kabupaten Kapuas Hulu, Sintang, dan Melawi. 
Meninjau peta normal streamlinebulan Februari untuk periode yang sama yakni 1981-2010, maka angin yang bertiup untuk wilayah Indonesia secara umunya yaitu dari barat, dan secara khusus di wilayah Kalimantan Barat angin yang berhembus adalah dari Samudra Pasifik yang kemudian memasuki Laut China Selatan, Selat Karimata dan kemudian berbelok menuju Australia sehingga terdapat daerah belokan angin (shearline) di sekitar Kalimantan Barat dengan kecepatan angin berkisar 510 knots (lihat Gambar 5). Tidak ada perbedaan yang signifikan antara arah dan kecepatan angin pada bulan Januari dan Februari. Angin yang berhembus dari Samudera Pasifik tersebut membawa banyak uap air yang cukup untuk proses pembentukan awan hujan. Adanya shearline mengakibatkan massa udara berkumpul di sekitar lokasi shearline sehingga memicu aktivitas konvektif pembentukan awanawan hujan.

\subsection{Normal curah hujan dan streamline bulan Maret}

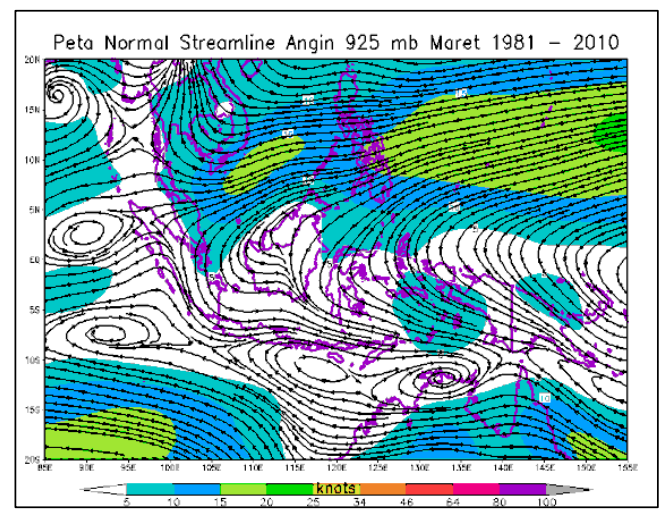

Gambar 6. Peta normal streamline Indonesia bulan Maret periode 1981-2010

Berdasarkan Gambar 3, diketahui bahwa intensitas curah hujan yang terjadi di Kalimantan Barat pada bulan Maret bervariasi. Di sebagian wilayah Kabupaten/Kota: Sambas, Singkawang, Bengkayang, Landak, Mempawah, Pontianak, Kubu Raya, dan Ketapang curah hujan yang terjadi dalam kategori menengah bagian bawah, yakni secara umum berkisar 201-300 mm/bulan, bahkan di sebagian kecil wilayah Kabupaten Sambas dan Mempawah hanya berkisar 101-150 mm/bulan. Di sebagian wilayah Kabupaten Sanggau, Sekadau, Kayong Utara, Melawi, Sintang, dan Kapuas Hulu curah hujan yang terjadi berkisar 301-400 $\mathrm{mm}$ /bulan dengan kategori tinggi. Sedangkan di sebagian wilayah Kabupaten
Sintang dan Kapuas Hulu curah hujan yang terjadi berkisar 400-500 mm/bulan dengan kategori sangat tinggi.

Berdasarkan peta normal streamlinebulan Maret untuk periode yang sama yakni 1981-2010, sama seperti pada Bulan Januari maupun Februari, angin yang bertiup untuk wilayah Indonesia secara umum yaitu dari barat, dan secara khusus di wilayah Kalimantan Barat angin yang berhembus adalah dari Samudra Pasifik yang kemudian memasuki Laut China Selatan, Selat Karimata dan kemudian berbelok menuju Australia sehingga terdapat daerah belokan angin (shearline) di sekitar Kalimantan Barat dengan kecepatan angin calm/tenang (lihat Gambar 6). Selain itu, terdapat pula daerah pertemuan angin/konvergensi di sekitar daerah hulu Kalimantan Barat (Kabupaten Kapuas Hulu dan sekitarnya). Angin yang berhembus dari Samudera Pasifik tersebut membawa banyak uap air yang cukup untuk proses pembentukan awan hujan. Selain itu, adanya daerah pertemuan angin/konvergensi mengakibatkan massa udara berkumpul di sekitar lokasi konvergensi sehingga memicu aktivitas konvektif pembentukan awan-awan hujan.

\subsection{Normal curah hujan dan streamline bulan April}

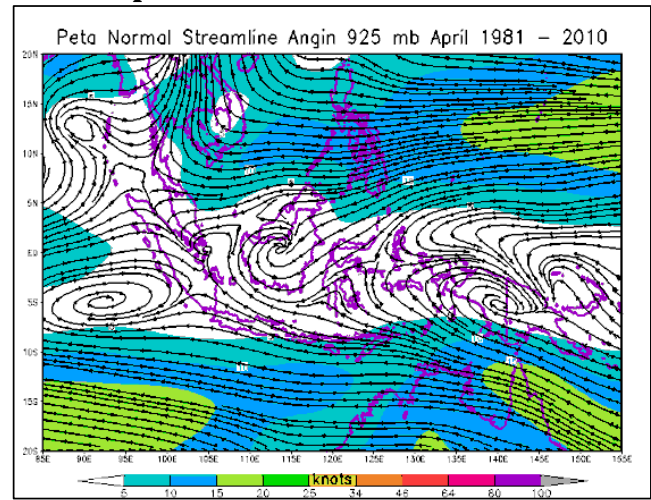

Gambar 7. Peta normal streamline Indonesia bulan April periode 1981-2010

Berdasarkan Gambar 3, diketahui bahwa intensitas curah hujan yang terjadi di Kalimantan Barat pada bulan April dalam kategori menengah-tinggi yaitu dengan intensitas curah hujan berkisar 201-400 $\mathrm{mm} /$ bulan. Namun di sebagian wilayah Kabupaten Sambas dan Bengkayang, curah hujan yang terjadi dalam kategori menengah bagian bawah yakni berkisar 101-150 mm/bulan. Sebaliknya di sebagian wilayah Kabupaten Sintang, Kapuas Hulu, Melawi dan Kapuas Hulu curah hujan yang 
terjadi berkisar 301-400 mm/bulan dengan kategori tinggi, bahkan di sebagian wilayah Kabupaten Kapuas Hulu curah hujan yang terjadi berkisar $400 \mathrm{~s} / \mathrm{d}>500 \mathrm{~mm} /$ bulan dengan kategori sangat tinggi.

Meninjau peta normal streamlinebulan Maret untuk periode yang sama yakni 1981-2010, berbeda dengan bulan-bulan sebelumnya, angin yang bertiup untuk wilayah Indonesia bagian utara secara umum yaitu dari barat sedangkan wilayah Indonesia bagian selatan berhembus dari timur, dan secara khusus di wilayah Kalimantan Barat angin yang berhembus adalah dari Samudera Pasifik yang kemudian memasuki Laut China Selatan, Selat Karimata dan kemudian bertemu dengan angin timuran yang masuk ke Laut Jawa dan berbelok di sekitar Pulau Kalimantan sehingga tedapat daerah pusaran angin masuk/siklonik, khususnya di daerah hulu/timur Kalimantan Barat dengan kecepatan angin calm/tenang (lihat Gambar 7).

\subsection{Normal curah hujan dan streamline bulan Mei}

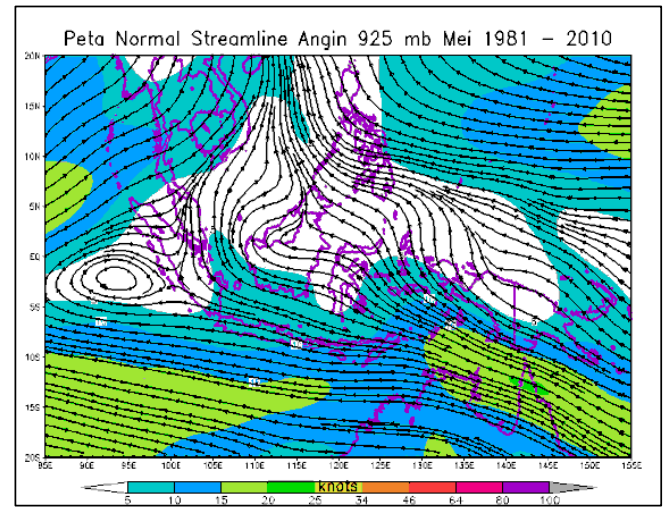

Gambar 8. Peta normal streamline Indonesia bulan Mei periode 1981-2010

Berdasarkan Gambar 3, diketahui bahwa intensitas curah hujan yang terjadi di Kalimantan Barat pada bulan Mei secara umum dalam kategori menengah yaitu dengan intensitas curah hujan berkisar 101-300 mm/bulan. Namun di sebagian wilayah Kabupaten Sintang dan Kapuas Hulu curah hujan yang terjadi berkisar 301$400 \mathrm{~mm} /$ bulan dengan kategori tinggi bahkan dapat mencapai $>400 \mathrm{~mm} /$ bulan dengan kategori sangat tinggi.

Saat kita tinjau anginnya berdasarkan peta normal streamlineBulan Juni untuk periode yang sama yakni 1981-2010, angin yang bertiup untuk wilayah Indonesia secara umum dari timur dan secara khusus di wilayah Kalimantan Barat angin yang berhembus adalah dari Australia yang kemudian memasuki Laut Jawa dan berbelok di sekitar Selat Karimata dan Kalimantan Barat dengan kecepatan berkisar 5-10 knots (lihat Gambar 8).

\subsection{Normal curah hujan dan streamline bulan Juni}

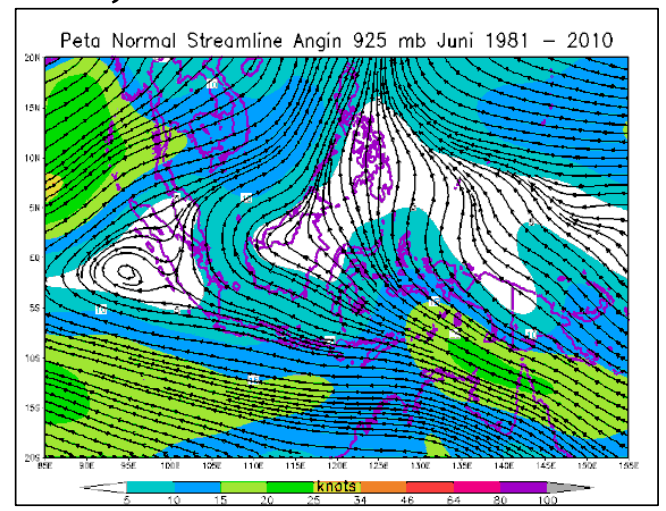

Gambar 9. Peta normal streamline Indonesia bulan Juniperiode 1981-2010

Berdasarkan Gambar 3, diketahui bahwa intensitas curah hujan yang terjadi di Kalimantan Barat pada bulan Mei secara umum dalam kategori menengah yaitu dengan intensitas curah hujan berkisar 101-300 mm/bulan. Namun di sebagian wilayah Kabupaten Sintang dan Kapuas Hulu curah hujan yang terjadi berkisar 301$400 \mathrm{~mm} /$ bulan dengan kategori tinggi bahkan dapat mencapai $>400 \mathrm{~mm} /$ bulan dengan kategori sangat tinggi.

Saat kita tinjau anginnya berdasarkan peta normal streamlineBulan Juni untuk periode yang sama yakni 1981-2010, angin yang bertiup untuk wilayah Indonesia secara umum dari timur dan secara khusus di wilayah Kalimantan Barat angin yang berhembus adalah dari Australia yang kemudian memasuki Laut Jawa dan berbelok di sekitar Selat Karimata dan Kalimantan Barat dengan kecepatan berkisar 5-10 knots (lihat Gambar 9). 


\subsection{Normal curah hujan dan streamline} bulan Juli

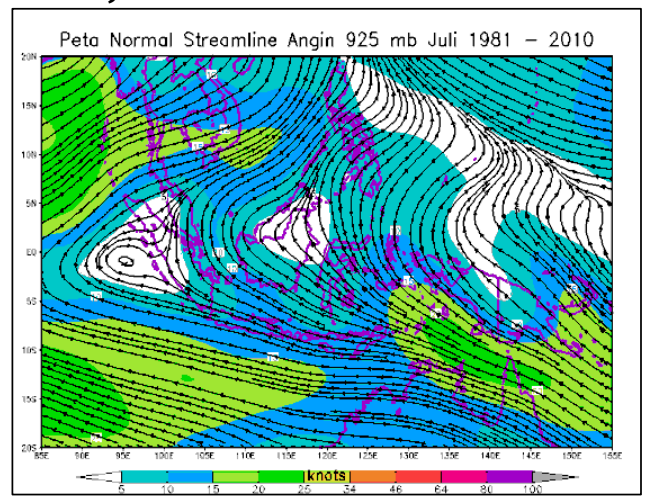

Gambar 10. Peta normal streamline

Indonesia bulan Juli periode 1981-2010

Berdasarkan Gambar 3, diketahui bahwa intensitas curah hujan yang terjadi di Kalimantan Barat pada bulan Juli secara umum dalam kategori menengah yaitu dengan intensitas curah hujan berkisar 101-300 mm/bulan. Di sebagian wilayah Kabupaten Ketapang, Kubu Raya, dan Sambas, curah hujan yang terjadi berkisar 101-150 mm/bulan termasuk dalam kategori menengah bagian bawah.

Bila dikaitkan dengan angin, maka berdasarkan peta normal streamlinebulan Juli untuk periode yang sama yakni 19812010, angin yang bertiup untuk wilayah Indonesia secara umum dari timur dan secara khusus di wilayah Kalimantan Barat angin yang berhembus adalah dari Australia yang kemudian memasuki Laut Jawa dan berbelok di sekitar Selat Karimata dan Kalimantan Barat dengan kecepatan berkisar 5-10 knots (lihat Gambar 10).

\subsection{Normal curah hujan dan streamline bulan Agustus}

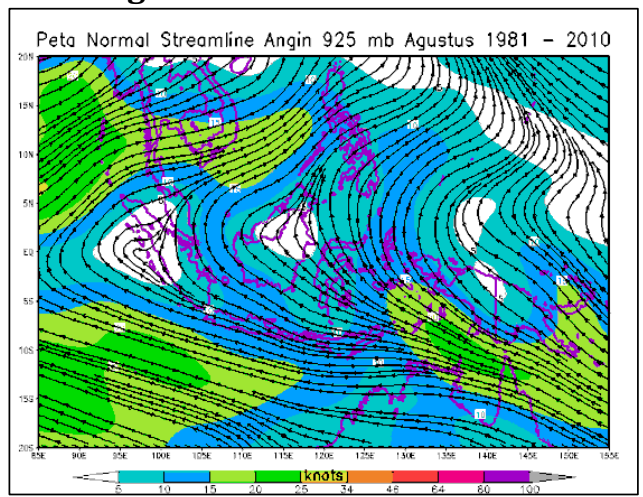

Gambar 11. Peta normalstreamline

Indonesia bulan Agustus periode 19812010

Berdasarkan Gambar 3, diketahui bahwa intensitas curah hujan yang terjadi di
Kalimantan Barat pada bulan Agustus secara umum dalam kategori menengah yaitu dengan intensitas curah hujan berkisar 101-300 mm/bulan. Namun di sebagian wilayah Kabupaten Sintang dan Kapuas Hulu, curah hujan yang terjadi berkisar 301-400 $\mathrm{mm} /$ bulan termasuk dalam kategori tinggi.

Melihat kondisi angin berdasarkan peta normal streamlineBulan Agustus untuk periode yang sama yakni 1981-2010, angin yang bertiup untuk wilayah Indonesia secara umum dari timur dan secara khusus di wilayah Kalimantan Barat angin yang berhembus adalah dari Australia yang kemudian memasuki Laut Jawa dan berbelok di sekitar Selat Karimata dan Kalimantan Barat dengan kecepatan berkisar 5-15 knots (lihat Gambar 11).

\subsection{Normal curah hujan dan streamline} bulan September

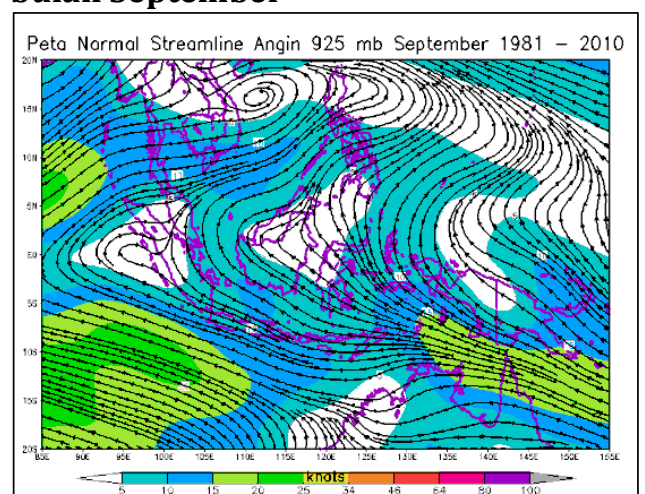

Gambar 12. Peta normal streamline Indonesia bulan September periode 19812010

Berdasarkan Gambar 3, diketahui bahwa intensitas curah hujan yang terjadi di Kalimantan Barat pada bulan September secara umum dalam kategori menengah yaitu dengan intensitas curah hujan berkisar 201-300 mm/bulan. Namun di sebagian wilayah Kabupaten Sintang, Kapuas Hulu, dan Mempawah curah hujan yang terjadi berkisar $301-400 \mathrm{~mm} /$ bulan termasuk dalam kategori tinggi.

Bila dikaitkan dengan angin, maka berdasarkan peta normal streamlinebulan September untuk periode yang sama yakni 1981-2010, angin yang bertiup untuk wilayah Indonesia secara umum dari timuran dan secara khusus di wilayah Kalimantan Barat angin yang berhembus adalah dari Australia yang kemudian memasuki Laut Jawa dan berbelok di sekitar Selat Karimata dan Kalimantan Barat 
dengan kecepatan berkisar 5-15 knots (lihat Gambar 12).

\subsection{Normal curah hujan dan streamline bulan Oktober}

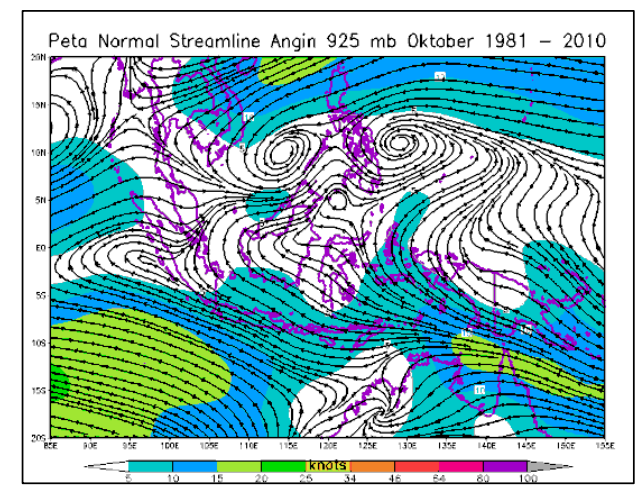

Gambar 13. Peta normal streamline Indonesia bulan Oktober periode 19812010

Berdasarkan Gambar 3, diketahui bahwa intensitas curah hujan yang terjadi di Kalimantan Barat pada bulan Oktober secara umum dalam kategori tinggi yaitu dengan intensitas curah hujan berkisar 301-400 mm/bulan.

Saat kita tinjau anginnya berdasarkan peta normal streamlinebulan Oktober untuk periode yang sama yakni 1981-2010, angin yang bertiup untuk wilayah Indonesia secara umum dari timur dan secara khusus di wilayah Kalimantan Barat angin yang berhembus adalah dari Australia yang kemudian memasuki Laut Jawa dan berbelok di sekitar Selat Karimata dan Kalimantan Barat sehingga terdapat shearline, dengan kecepatan berkisar 0-5 knots (lihat Gambar 13).

\subsection{Normal curah hujan dan streamline} bulan November

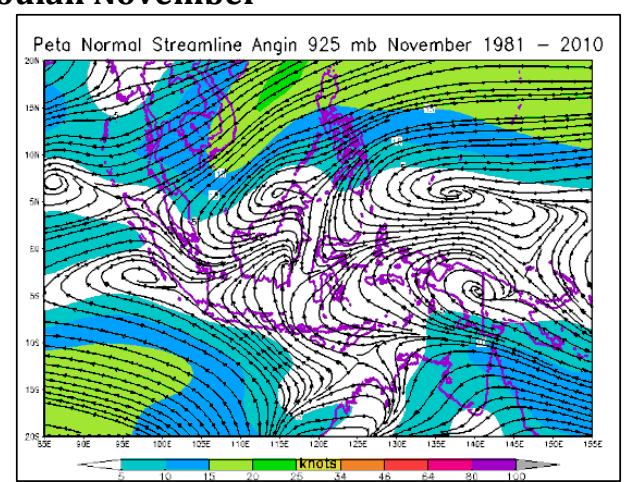

Gambar 14. Peta normal streamline Indonesia bulan November periode 19812010

Berdasarkan Gambar 3, diketahui bahwa intensitas curah hujan yang terjadi di
Kalimantan Barat pada bulan November secara umum dalam kategori tinggi yaitu dengan intensitas curah hujan berkisar 301-400 mm/bulan. Namun di beberapa wilayah Kabupaten Ketapang, Kayong Utara, Sintang, Sekadau, Kapuas Hulu, Melawi terdapat curah hujan dengan intensitas 401-500 mm/bulan, bahkan mencapai $>500 \mathrm{~mm} /$ bulan dengan kategori tinggi-sangat tinggi.

Bila dikaitkan dengan angin, maka berdasarkan peta normal streamlinebulan November untuk periode yang sama yakni 1981-2010, angin yang bertiup untuk wilayah Indonesia bagian utara secara umum yaitu dari baratan sedangkan wilayah Indonesia bagian selatan berhembus dari timuran, dan secara khusus di wilayah Kalimantan Barat terdapat daerah pertemuan angin/konvergensi antara angin dari selatan dan utara Kalimantan Barat (lihat Gambar 14).

\subsection{Normal curah hujan dan streamline bulan Desember}

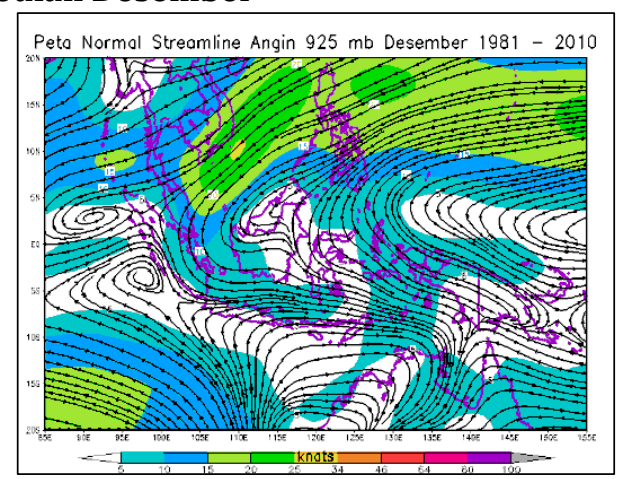

Gambar 15. Peta normal streamline Indonesia bulan Desember periode 19812010

Berdasarkan Gambar 3, diketahui bahwa intensitas curah hujan yang terjadi di Kalimantan Barat pada bulan Desember secara umum dalam kategori tinggi-sangat tinggi yaitu dengan intensitas curah hujan berkisar 301-500 mm/bulan. Di beberapa wilayah Kabupaten Ketapang, Sintang, Kapuas Hulu terdapat intensitas mencapai $>500 \mathrm{~mm} /$ bulan dalam kategori sangat tinggi.

Bila dikaitkan dengan angin, maka berdasarkan peta normal streamline bulan Desember untuk periode yang sama yakni 1981-2010, angin yang bertiup di wilayah Indonesia secara umum dari barat, dan secara khusus di wilayah Kalimantan Barat dan Selat Karimata terdapat daerah belokan angin/shearline (lihat Gambar 15). 
Rangkuman dari hubungan antara normal curah hujan dan pola angin pada normal streamline di Kalimantan Barat dapat dilihat pada Tabel 1 berikut:

Tabel 1. Analisis angin dan kategori hujan di Kalimantan Barat

\begin{tabular}{|c|c|c|c|}
\hline Bulan & $\begin{array}{l}\text { Analisis angin pada } \\
\text { normal Streamline }\end{array}$ & $\begin{array}{c}\text { Kategori } \\
\text { hujan }\end{array}$ & $\begin{array}{c}\text { Lokasi kejadian } \\
\text { (Kabupaten/Kota) }\end{array}$ \\
\hline \multirow[t]{3}{*}{ Januari } & \multirow[t]{3}{*}{$\begin{array}{l}\text { Baratan, terdapat daerah } \\
\text { belokan } \\
\text { angin/shearlinedi sekitar } \\
\text { Kalimantan Barat }\end{array}$} & Menengah & $\begin{array}{l}\text { Sambas, Singkawang, Bengkayang, Landak, } \\
\text { Mempawah, Pontianak, Kubu Raya, Kayong } \\
\text { Utara, Ketapang, Sekadau, Sintang, Kapuas } \\
\text { Hulu }\end{array}$ \\
\hline & & Tinggi & Merata di wilayah Kalimantan Barat \\
\hline & & Sangat Tinggi & $\begin{array}{l}\text { Sambas, Bengkayang, Kapuas Hulu, Sintang, } \\
\text { Sekadau, Kayong Utara, Ketapang }\end{array}$ \\
\hline \multirow[t]{3}{*}{ Februari } & \multirow{3}{*}{$\begin{array}{l}\text { Baratan, terdapat daerah } \\
\text { belokan } \\
\text { angin/shearlinedi sekitar } \\
\text { Kalimantan Barat }\end{array}$} & Menengah & Merata di wilayah Kalimantan Barat \\
\hline & & Tinggi & $\begin{array}{l}\text { Kapuas Hulu, Sintang, Sekadau, Ketapang, } \\
\text { Bengkayang }\end{array}$ \\
\hline & & Sangat Tinggi & Kapuas Hulu \\
\hline \multirow[t]{3}{*}{ Maret } & \multirow{3}{*}{$\begin{array}{l}\text { Baratan, terdapat daerah } \\
\text { konvergensi/pumpunandi } \\
\text { sekitar Kalimantan Barat }\end{array}$} & Menengah & $\begin{array}{l}\text { Merata di wilayah Kalimantan Barat kecuali } \\
\text { Kab. Sintang, Melawi }\end{array}$ \\
\hline & & Tinggi & $\begin{array}{l}\text { Singkawang, Landak, Sanggau, Sekadau, } \\
\text { Kayong Utara }\end{array}$ \\
\hline & & Sangat Tinggi & Sintang, Melawi, Kapuas Hulu \\
\hline \multirow[t]{3}{*}{ April } & \multirow{3}{*}{$\begin{array}{l}\text { Terdapat daerah pusaran } \\
\text { angin masuk/siklonikdi } \\
\text { sekitar Kalimantan Barat }\end{array}$} & Menengah & Merata di wilayah Kalimantan Barat \\
\hline & & Tinggi & $\begin{array}{l}\text { Bengkayang, Mempawah, Landak, Sanggau, } \\
\text { Sekadau, Kayong Utara, Ketapang, Sintang, } \\
\text { Melawi, Kapuas Hulu }\end{array}$ \\
\hline & & Sangat Tinggi & Kapuas Hulu \\
\hline \multirow[t]{3}{*}{ Mei } & \multirow{3}{*}{$\begin{array}{l}\text { Timuran, terdapat daerah } \\
\text { belokan } \\
\text { angin/shearlinedi sekitar } \\
\text { Kalimantan Barat }\end{array}$} & Menengah & $\begin{array}{l}\text { Merata di wilayah Kalimantan Barat kecuali } \\
\text { sebagian Kab. Sintang, Kayong Utara, } \\
\text { Ketapang, Kapuas Hulu, Mempawah }\end{array}$ \\
\hline & & Tinggi & $\begin{array}{l}\text { Sintang, Kapuas Hulu, Kayong Utara, } \\
\text { Ketapang, Mempawah }\end{array}$ \\
\hline & & Sangat Tinggi & --- \\
\hline \multirow[t]{3}{*}{ Juni } & \multirow{3}{*}{$\begin{array}{l}\text { Timuran, terdapat daerah } \\
\text { belokan } \\
\text { angin/shearlinedi sekitar } \\
\text { Kalimantan Barat }\end{array}$} & Menengah & Merata di wilayah Kalimantan Barat \\
\hline & & Tinggi & Sintang, Kapuas Hulu \\
\hline & & Sangat Tinggi & Sintang, Kapuas Hulu \\
\hline \multirow[t]{3}{*}{ Juli } & \multirow{3}{*}{$\begin{array}{l}\text { Timuran, terdapat daerah } \\
\text { belokan } \\
\text { angin/shearlinedi sekitar } \\
\text { Kalimantan Barat }\end{array}$} & Menengah & Merata di wilayah Kalimantan Barat \\
\hline & & Tinggi & -- \\
\hline & & Sangat Tinggi & --- \\
\hline \multirow[t]{3}{*}{ Agustus } & \multirow{3}{*}{$\begin{array}{l}\text { Timuran, terdapat daerah } \\
\text { belokan } \\
\text { angin/shearlinedi sekitar } \\
\text { Kalimantan Barat }\end{array}$} & Menengah & Merata di wilayah Kalimantan Barat \\
\hline & & Tinggi & Sintang, Kapuas Hulu \\
\hline & & Sangat Tinggi & --- \\
\hline \multirow[t]{3}{*}{ September } & \multirow{3}{*}{$\begin{array}{l}\text { Timuran, terdapat daerah } \\
\text { belokan } \\
\text { angin/shearlinedi sekitar } \\
\text { Kalimantan Barat }\end{array}$} & Menengah & Merata di wilayah Kalimantan Barat \\
\hline & & Tinggi & Sintang, Kapuas Hulu, Mempawah \\
\hline & & Sangat Tinggi & --- \\
\hline \multirow[t]{2}{*}{ Oktober } & \multirow[t]{2}{*}{$\begin{array}{l}\text { Timuran, terdapat daerah } \\
\text { belokan }\end{array}$} & Menengah & $\begin{array}{l}\text { Merata di wilayah Kalimantan Barat kecuali } \\
\text { Kab. Melawi, Mempawah, Bengkayang }\end{array}$ \\
\hline & & Tinggi & Merata di wilayah Kalimantan Barat \\
\hline
\end{tabular}




\begin{tabular}{|c|c|c|c|}
\hline Bulan & $\begin{array}{l}\text { Analisis angin pada } \\
\text { normal Streamline }\end{array}$ & $\begin{array}{l}\text { Kategori } \\
\text { hujan }\end{array}$ & $\begin{array}{l}\text { Lokasi kejadian } \\
\text { (Kabupaten/Kota) }\end{array}$ \\
\hline & $\begin{array}{l}\text { angin/shearlinedi sekitar } \\
\text { Kalimantan Barat }\end{array}$ & Sangat Tinggi & Sintang, Kapuas Hulu \\
\hline \multirow[t]{3}{*}{ November } & \multirow{3}{*}{$\begin{array}{l}\text { Terdapat daerah } \\
\text { pertemuan } \\
\text { angin/konvergensidi } \\
\text { sekitar Kalimantan Barat }\end{array}$} & Menengah & Landak, Kubu Raya, Kapuas Hulu \\
\hline & & Tinggi & Merata di wilayah Kalimantan Barat \\
\hline & & Sangat Tinggi & $\begin{array}{l}\text { Kapuas Hulu, Sintang, Melawi, Sekadau, } \\
\text { Ketapang, Kayong Utara, Singkawang, } \\
\text { Mempawah }\end{array}$ \\
\hline \multirow[t]{3}{*}{ Desember } & \multirow{3}{*}{$\begin{array}{l}\text { Baratan, terdapat daerah } \\
\text { belokan } \\
\text { angin/shearlinedi sekitar } \\
\text { Kalimantan Barat }\end{array}$} & Menengah & Landak, Pontianak, Kubu Raya, Kapuas Hulu \\
\hline & & Tinggi & Merata di wilayah Kalimantan Barat \\
\hline & & Sangat Tinggi & $\begin{array}{l}\text { Kapuas Hulu, Sintang, Melawi, Sanggau, } \\
\text { Sekadau, Ketapang, Kayong Utara, Kubu } \\
\text { Raya, Bengkayang, Sambas }\end{array}$ \\
\hline
\end{tabular}

Menurut Tjasyono [16], hujan dapat dibagi menjadi hujan konvektif, hujan orografi, hujan konvergensi/frontal berdasarkan mekanisme pembentukan awannya. Berdasarkan pembahasan-pembahasan di atas dan dikaitkan dengan teori Tjasyono tersebut, hujan yang terjadi hampir sepanjang tahun dengan intensitas cukup besar di Kalimantan Barat dikarenakan wilayah Kalimantan Barat merupakan daerah yang mengalami konveksi (pemanasan) cukup tinggi sepanjang tahun. Meninjau letak geografis Kalimantan Barat yang berada di sekitar lintang $0^{\circ}$, memiliki banyak sungai serta2 (dua) danau besar di Kabupaten Kapuas Hulu, mengakibatkan tersedianya sumber uap air yang cukup untuk proses konveksi yang selanjutnya berkondensasi menjadi awan-awan hujan (dapat dilihat kembali pada Gambar 1). Selain itu, daerah hulu/timur Kalimantan Barat yang memiliki jajaran perbukitan akan menjadi daerah depan gunung dan menjadi daerah turunnya hujan. Mengingat ketersediaan sumber uap air untuk proses konveksi dan kondensasi juga cukup banyak yang berasal dari kompleks Danau Sentarum di Kabupaten Kapuas Hulu, maka daerah hulu/timur Kalimantan Barat memiliki curah hujan rata-rata yang lebih tinggi daripada daerah barat Kalimantan Barat. Jika angin umum/monsun yang berhembus dari barat, maka angin lokal (angin lembah) yang selanjutnya mengakibatkan pembetukan awan hujan karena orografisakan semakin kuat.

\section{Kesimpulan}

Secara umum puncak hujan di Kalimantan Barat terjadi pada Maret-April dan NovemberDesember, sedangkan lembah hujan terjadi pada Februari dan Juli-Agustus. Secara spesifik daerah hulu Kalimantan Barat memiliki curah hujan lebih tinggi daripada daerah hilir Kalimantan Barat. Secara umum angin yang berhembus di wilayah Indonesia pada November-Maret adalah dari baratan, sedangkan pada Mei-September berhembus dari timuran. Selain itu, bulan April dan Oktober jika ditinjau dari massa udara yang berhembus adalah sebagai masa transisi.

Pada Maret-April dimana merupakan puncak hujan pertama di Kalimantan Barat, terbentuk daerah konvergensi di daerah hulu Kalimantan Barat (Maret) dan terdapat daerah siklonik di Kalimantan Barat (April). Pada puncak hujan kedua yaitu November-Desember, terdapat daerah konvergensi/pertemuan angin di Kalimantan Barat (November) dan adanya daerah belokan angin di Kalimantan Barat (Desember).

\section{Ucapan terima kasih}

Penulis mengucapkan terima kasih yang sebesar-besarnya atas motivasi, sarana dan prasarana, serta kesempatan melanjutkan pendidikan kepada Bapak Bambang Hargiyono selaku Kepala Stasiun Meteorologi Supadio periode 2008-2017, Ibu Erika Mardiyanti selaku Kepala Stasiun Meteorologi Supadio periode 2017-2020, serta Bapak Nanang Buchori selaku Kepala Stasiun Meteorologi Supadio periode 2020-sekarang.

\section{Daftar Pustaka}

[1] Tjasyono, Bayong, Klimatologi Terapan, FMIPA Institut Teknologi Bandung, 1995.

[2] http://www.kalbarprov.go.id/, 2015. "Gambaran Umum Aspek Geografis Kalimantan Barat" (Jumat, 24Juli 2020 17.00 WIB)

[3] Yudha P., Rizky, Kajian Keterkaitan Komponen Angin Terhadap Anomali Curah Hujan di Stasiun Hasanuddin Makassar, Skripsi, Sekolah Tinggi Meteorolgi Klimatologi dan Geofisika, Tangerang Selatan, 2015. 
[4] Nuraya, Tia, and Ihwan, Andi, and Apriansyah, Analisis Hujan Ekstrim Berdasarkan Parameter Angin dan Uap Air di Kototabang Sumatera Barat, PRISMA FISIKA, Vol. IV, No. 01, Hal. 22-27, 2016.

[5] Rahmani U., Irine, and Jumarang, Muh Ishak, and Apriansyah, Analisis Hujan Ekstrim Perhitungan Potensi Energi Angin di Kalimantan Barat, PRISMA FISIKA, Vol. VI, No. 01, Hal. 65-69, 2018.

[6] Agus W., Paulus, Analisa Cuaca I, Akademi Meteorologi dan Geofisika (AMG) Jakarta, 2011.

[7] Soepangkat., Pendahuluan Meteorologi, Balai Pendidikan dan Latihan Meteorologi dan Geofisika (BPLMG) Jakarta, 1994.

[8] Agus W., Paulus, Analisa Cuaca II, Akademi Meteorologi dan Geofisika (AMG) Jakarta, 2009.

[9] Tjasyono, Bayong dan Woro, Sri, Meteorologi Indonesia 2, Badan Meteorologi dan Geofisika (BMG) Jakarta, 2006.

[10] BMKG, 2010. Press Release Kondisi Cuaca Ekstrim dan Iklim Tahun 2010-2011, (http://data.bmkg.go.id/share/Dokumen/ press $\% 20$ release $\% 20$ kondisi $\% 20$ cuaca $\% 2$ 0ekstrim\%20dan\%20iklim\%20tahun\%20 2010-2011.pdf), diakses tanggal 07 April 2016.

[11] http://www.kalbarprov.go.id/, 2015. "Gambaran Umum Aspek Geografis Kalimantan Barat" (Selasa, 23 Agustus 2016 $21.00 \mathrm{WIB})$

[12] http://www.bakosurtanal.go.id/, 2004. "Peta Dinding Provinsi Kalimantan Barat" (Selasa, 23 Agustus 201621.00 WIB)

[13] Fitriyawita, Mega, Kajian Interaksi Aktivitas Konvektif Angin Darat Dan Angin Laut Menggunakan Wrf-Arw, Skripsi, Program Sarjana Terapan Meteorologi, Sekolah Tinggi Meteorologi Klimatologi dan Geofisika, Tangerang Selatan, 2015.

[14] Soepangkat., Pendahuluan Meteorologi, Balai Pendidikan dan Latihan Meteorologi dan Geofisika (BPLMG) Jakarta, 1994.

[15] Agus W., Paulus, Analisa Cuaca I, Akademi Meteorologi dan Geofisika (AMG) Jakarta, 2011.

[16] Tjasyono, Bayong dan Woro, Sri, Meteorologi Indonesia 2, Badan Meteorologi dan Geofisika (BMG) Jakarta, 2006. 